The study was carried out in 5 processing plants which differed greatly by their production capacity, slaughter equipment, working organization and type of production.

The data were collected over a period of one year and concern 660 different stocks from 289 producers.

The results show that the alteration factors due to condition of production are very limited. The total factors due to multiple origins (poultry house, methods of capture) are important.

The alteration factors due to the technological handling in the processing plant appear to be the most important whatever the processing plant concerned.

With identical appreciation criteria, the variation of the average rate of declassification is very important. The problem for a given processing plant is to lower the average rate and to limit the fluctuations close to this average.

In a great number of cases, improvements are possible, but they have to be considered at each stage of production.

\title{
ORIGIN OF SOME MICRO-ORGANISMS PRESENT ON POULTRY CARCASSES
}

\author{
Cécile LAHELLEC, C. MEURIER et G. BENNEJEAN \\ Station expérimentale d'Aviculture de Ploufragan, \\ 22440 Ploufragan
}

The origin of some micro-organisms present on poultry carcasses (Pseudomonas as spoilage micro-oganisms, Salmonellae and Staphylococci as pathogenic micro-organisms), has been studied.

The qualitative study of different psychrotrophic micro-organism discovered in three processing plants has made clear that Pseudomonas are conveyed with water especially during evisceration.

The origin of Salmonellae has been investigated in three processing plants, one of them slaughtering broilers and the two others slaughtering turkeys. The results show that some chickens or turkeys are safe carriers of Salmonellae and that those micro-organisms are spread over different steps of the processing line.

The origin, human or avian, of Staphylococci has also been investigated. It seems that serological methods could give interesting results.

\section{HELATIONSHIP BETWEEN THE SIALIC ACID CONTENT OF OVOMUCIN AND THE HEIGHT OF THE EGG WHITE GEL}

\author{
B. SAUVEUR
}

avec la collaboration technique de $\mathrm{M}^{\mathrm{me}}$ Huguette Antoine

Station de Recherches avicoles,

Centre de Recherches de Tours, I. N. R. A.,

Nouzilly, 37380 Monnaie

An investigation has been made on the changes in sialic acid (NANA) content of ovomucin complex extracted from the thick egg white. Two circumstances which modify the height of the egg white gel were studied. 
I. Eggs were stored in an atmosphere containing o or 2 p. Ioo of carbon dioxide. Without $\mathrm{CO}_{2}$, the thinning of thick egg white was accompanied by a decrease of both total ovomucin and NANA content of this precipitate (fig. I, 2) while its $\mathrm{pH}$ value was enhanced (table $\mathrm{I}$ ). The decrease of total ovomucin content excepted, all these alterations were suppressed by 2 p. Iоo of $\mathrm{CO}_{2}$ in the storage atmosphere.

2. Eggs produced by hens made acidotic by a diet containing 3 p. Ioo of $\mathrm{NH}_{4} \mathrm{Cl}$ were also studied. Increase in the height of the thick white was accompanied by a small, non significant increase in precipitable ovomucin complex without any variation of its NANA content (table 2).

3. These results are discussed in relation to the hypothesis of RoBInson (1972) which supposed that NANA can participate in the gel structure of the thick white. It is proposed that, during egg storage, $\mathrm{CO}_{2}$ acts through a protection of the $\beta$-components of ovomucin (carbohydrate rich fraction).

4. Attention is called on the specific effect of divalent cations in the control of the height of the thick egg white gel according to the previous hypothesis of SAUveUR (I970 and 1971).

\title{
THE EFFECT OF IN VITRO EGG PLUMPING ON EGg WHITE PHYSICO-CHEMICAL PROPERTIES
}

\author{
B. SAUVEUR \\ avec la collaboration technique de $\mathrm{M}^{\mathrm{me}}$ Huguette Antorne \\ Station de Recherches avicoles, \\ Centre de Recherches de Tours, I. N. R. A., \\ Nouzilly, 37380 Monnaie
}

The purpose of this investigation was to study the possibilities of modifying the physicochemical properties of the egg-white by plumping the uterine eggs in artificial solutions. Soft shelled eggs were expelled out of uterus six hours after the former oviposition and immersed during four hours in either distilled water, or solutions of $\mathrm{NaCl}, \mathrm{CaCl}_{2}, \mathrm{MgCl}$, and glucose at $300 \mathrm{mOsm}$ (ten eggs in each treatment).

The hourly weight gain of the egg and water content of the egg-white after four hours are reported in table $\mathrm{I}$. Whatever the nature of the solution, the rate of plumping was higher during the first two hours than during the two following. The final egg-white water content was as follows : Glucose $<\mathrm{MgCl}_{2}<\mathrm{CaCl}_{2}<\mathrm{NaCl}<\mathrm{H}_{2} \mathrm{O}$. This result is in good agreement with general laws of water imbibing power of polyelectrolytes; it confirms that divalent cations ( $\mathrm{Mg}$ and $\mathrm{Ca}$ ) are bound more extensively than $\mathrm{Na}$ to egg-white organic matter.

Table 2 refers to some properties of egg-white, estimated after the in vitro hydratation. The height of thick white (first column) was increased by $\mathrm{CaCl}_{2}, \mathrm{MgCl}_{2}$ or glucose, relatively to $\mathrm{H}_{2} \mathrm{O}$ or $\mathrm{NaCl}$. So it was quite possible to modify this very important character of egg-white quality, without any alteration of protein content. It appeared that high values of Haugh units required a great cohesion of peptidic chains (obtainable by high levels of $\mathrm{Ca}$ and $\mathrm{Mg}$ ) and, consequently, a low water content of the thick white.

The reported values of viscosity have to be considered with caution because they were 